\title{
$\mathrm{MoSi}_{2}-\mathrm{ZrO}_{2}$ 二成分系の 焼結
}

\author{
松 尾 重 友・本 間 一 元 \\ （東芝中央研究所）（東芝電興株式会社）
}

\section{Sintering in the Binary System $\mathrm{MoSi}_{2}-\mathrm{ZrO}_{2}$}

\author{
By \\ Shigetomo MATSUO and Kazumoto HOMMA \\ (Central Research Laboratory, Tokyo Shibaura Electric Co., Ltd. \\ and Toshiba Denko Co., Ltd.)
}

\begin{abstract}
Molybdenum disilicide has recently been developed as an excellent heating element of high refractoriness and of high oxidation resistivity. The binary system of $\mathrm{MoSi}_{2}-\mathrm{ZrO}_{2}$ was studied for the purpose of improving the too low electrical resistivity of $\mathrm{MoSi}_{2}$ without changing the other favorable characteristics.

$\mathrm{ZrO}_{2}$ used was previously stabilized by dissolving $10 \mathrm{~mol} \%$ of $\mathrm{Y}_{2} \mathrm{O}_{3}$ at $1600^{\circ} \mathrm{C}$. Samples of six different chemical compositions differing from each other by $20 \%$ in $\mathrm{ZrO}_{2}$ content, were formed under the pressure of $6 \mathrm{ton} / \mathrm{cm}^{2}$ and sintered at five different temperatures between $1300^{\circ}$ and $1650^{\circ} \mathrm{C}$ in $\mathrm{H}_{2}$ gas.

The electrical resistivity, density and modulus of rupture were measured on sintered specimens and expressed as functions of sintering temperature, chemical composition and sintering time.

The density becomes minimum at about $60 \%$ of $\mathrm{ZrO}_{2}$ content and the modulus of rupture varies approximately with the density.

The electrical resistivity at a room temperature increases rapidly with the amount of $\mathrm{ZrO}_{2}$ above $60 \%$. The change of the electrical resistivity was also investigated up to the surface temperature of $1700^{\circ} \mathrm{C}$. The resistivity increases with temperature on the $\mathrm{MoSi}_{2}$ side, while decreases on the $\mathrm{ZrO}_{2}$ side.

The thermal shock test by repeated rapid heating and cooling between a room temperature and $1400^{\circ} \mathrm{C}$, showed that the samples of the medium composition had the least thermal shock resistance.

[Received Oct. 14, 1963]
\end{abstract}

I. 緒

空気中 $1700^{\circ} \mathrm{C}$ で使用可能な電気抵抗発熱体として $\mathrm{MoSi}_{2}$ を主体とする発熱体を先に開発したが,その電気 抵抗值が低いため必然的に高電流低電圧型である。 $\mathrm{MoSi}_{2}$ のすぐれた耐熱酸化性を減ずることなく電気抵

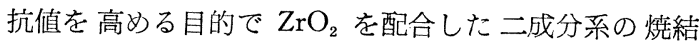
を行なった。

\section{II. 原料之実験方法}

\section{1 原料}

$\mathrm{MoSi}_{2}$ はドイツ Hermann C. Stark 社製平均粒径 $4 \mu$ の粉末でその化学分析值は Mo $63 \%, \mathrm{Si} 37 \%, \mathrm{Fe}$ $0.5 \%, \mathrm{C} 0.1 \%$ である. $\mathrm{ZrO}_{2}$ は $99.5 \%, \mathrm{ZrO}_{2}$ に固溶 させた $\mathrm{Y}_{2} \mathrm{O}_{3}$ は $99.99 \%$ 純度のものである.

多くの場合 $\mathrm{ZrO}_{2}$ は $\mathrm{MgO}$ または $\mathrm{CaO}$ を固溶せし めて安定化しているが， $\mathrm{MgO}$ による安定化は不完全で あり，また $\mathrm{CaO}$ にるる安定化は本実験の場合 $\mathrm{MoSi}_{2}$ の酸化の結果生ずる耐熱被膜である $\mathrm{SiO}_{2}$ と $\mathrm{CaO}$ とが
反応して融点の低い化合物を生じるので不適当である。 そこで本実験では $\mathrm{Y}_{2} \mathrm{O}_{3}$ により安定化させた $\mathrm{ZrO}_{2}$ を 用いた. $\mathrm{ZrO}_{2}-\mathrm{Y}_{2} \mathrm{O}_{3}$ 二元系において $\mathrm{Y}_{2} \mathrm{O}_{3} \quad 9 \sim 55 \mathrm{~mol}$ \%で立方晶 $\mathrm{ZrO}_{2}$ が形成される ${ }^{11}$.

まず $\mathrm{Y}_{2} \mathrm{O}_{3}$ 固溶条件決定のために $\mathrm{Y}_{2} \mathrm{O}_{3}$ 粉末 $10 \mathrm{~mol}$ \%を $\mathrm{ZrO}_{2}$ 粉末に混合 $6.5 \phi \times 20 \mathrm{~mm}$ の形状に 1 ton/ $\mathrm{cm}^{2}$ で成形し, 白金炉で $1300^{\circ} \sim 1700^{\circ} \mathrm{C}$ の温度で空気 中加熱を行った. 加熱処理試料の $\mathrm{X}$ 線解析は, 加熱前で は単斜晶 $\mathrm{ZrO}_{2}$ と $\mathrm{Y}_{2} \mathrm{O}_{3}$ の混合物であるが温度上昇と 共に単斜晶 $\mathrm{ZrO}_{2}$ の回折線強度は次第に減少し $1700^{\circ} \mathrm{C}$ ではほとんど立方晶 $\mathrm{ZrO}_{2}$ 単一相となった。他方上記と 同様に調製した武料を $1600^{\circ} \mathrm{C}$ 維持のまま $0.5 \sim 8$ 時間 加熱した試料の $\mathrm{X}$ 線解析では 4 時間処理で単斜晶 $\mathrm{ZrO}_{2}$ がほとんど認められず，8時間処理では完全に単斜晶 $\mathrm{ZrO}_{2}$ の回折線が消滅していた。 以上の予備実験により 実験試料たる安定化 $\mathrm{ZrO}_{2}$ としては $\mathrm{Y}_{2} \mathrm{O}_{3}$ を $10 \mathrm{~mol} \%$ 添加して $1600^{\circ} \mathrm{C} 8$ 時間維持 の加熱条件で単斜晶系の $\mathrm{ZrO}_{2}$ は完全に立方晶系に変態しているものと認められ 
る.とれを粉砕してほぼ度径 $10 \mu$ 程の粉として実験に 使用した.

\section{2 実 験 方 法}

II. 2.1 試料の成形焼結 $\mathrm{MoSi}_{2}$ と安定化 $\mathrm{ZrO}_{2}$ と を重量比で $20 \%$ おきに変えた配合組成は 6 通りある. これを冷間で成形圧 6 ton $/ \mathrm{cm}^{2}$ (バインダーなし)で 6.5 $\phi \times 18 \mathrm{~mm}$ の形状に成形し, $100 \times ッ シ ュ ~ \mathrm{Al}_{2} \mathrm{O}_{3}$ (粉純 度 $98 \%$ ）を詰め粉にしてモリブデン製容器につめ水素 炉で $1300^{\circ}, 1400^{\circ}, 1500^{\circ}, 1600^{\circ}, 1650^{\circ} \mathrm{C}$ の 5 段階の温 度でそれぞれ 30 分間維持した. 以上 30 種類の試料を 温度別焼結試料とした。

また同様の条件で各組成でとに冷間成形した試料を水 素炣で一定温度 $1600^{\circ} \mathrm{C}$ 亿維持し $0.5,1,2,4,8$ 時間 の各経過時間ごとに試料を取り出した. 以上 30 種類を 時間別焼結試料とした。

II. 2.2 焼結体の諸特性測定 前項の方法により焼 結を行なった計 60 通りの各試料についてその焼結密度, 抗折力, 常温および高温の電気抵抗, 耐熱衝擊性等の測 定を行なった.

抗折力は万能試験機により荷重速度 $5 \mathrm{~mm} / \mathrm{min}$., 試 料保持支点間隔 $12 \mathrm{~mm}$ の条件で測定した.

常温における電気抵抗值測定に関しては $\mathrm{ZrO}_{2} 40 \%$ 以下の低抵抗試料は四端子法によった。すなわち流通電 流を $600 \mathrm{~mA}$ とし試料に当てた針状電圧端子の電位差 を最小目盛 $1 \mu \mathrm{V}$ のポテンショメータにより测定して 求めた. また高抵抗試料の電気抵抗は振動容量型電位計 により测定した.

高温における電気抵抗值測定は 60 通りの試料全部に ついては行なわず,時間別試料のうち 1 時間焼結のもの， すなわち $1600^{\circ} \mathrm{C}$ で 1 時間焼結した 6 通りの組成の試料 についてのみ測定した. $\mathrm{ZrO}_{2} 40 \%$ 以下の低抵抗試料は 直接通電により発熱させ試料表面温度 $900^{\circ} \sim 1700^{\circ} \mathrm{C}$ に おける電気抵抗の変化を電圧降下法により測定した.

$\mathrm{ZrO}_{2} 60 \%$ 以上の高抵抗試料はカーボン発熱体による間 接加熱によって温度を上げた. 試料は発熱体の中央にあ けた穴に挿入し高周波ブリッジにより熱間の抵抗を測定 した. この際の温度測定はカーボン発熱体の表面温度で あり，その温度をもって試料の温度と見なした。

熱衝撃抵抗は $1600^{\circ} \mathrm{C}$ で 4 時間焼結した 6 通りの組成 のものをアルミナボートに入れ, あらかじめ $1400^{\circ} \mathrm{C} に$ 維持してある炭化珪素発熱体炉に入れ 10 分間維持した 後室温に急冷する過程を繰り返し龟裂の生ずる回数から 求めた。

\section{III. 実験結果とその考察}

\section{1 焼 結密度}

焼結密度はすべて理論密度に対する蔩密度の比を百分 率で示したもので述べる，各組成に対する理論密度值は
$\mathrm{X}$ 線回折の線果から $\mathrm{MoSi}_{2} 100 \%$ 組成の理論密度を $6.24 \mathrm{~g} / \mathrm{cm}^{3}, \mathrm{ZrO}_{2}$ 固溶体のそれを $6.0 \mathrm{~g} / \mathrm{cm}^{3}$ として求 めた (F. Hund ${ }^{2}$ による文献值は $6.09 \mathrm{~g} / \mathrm{cm}^{3}$ ).

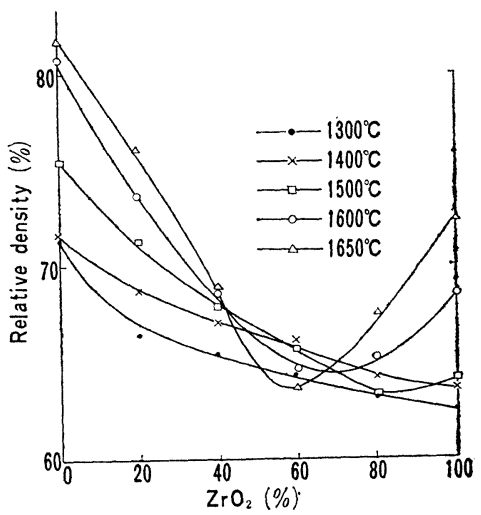

Fig. 1. Relations between density and composition for various sintering temperatures.
図-1 は温度 別焼結試料の密 度比を温度を因 子とし組成の関 数としてプロッ トした・組成中 $\mathrm{ZrO}_{2}$ 含有量 が 増すに従って密 度が減少しほぼ $60 \%$ で最小と なり,さらに $\mathrm{ZrO}_{2}$ が増加す ると再び上昇し てくる．との傾 向は燒結温度が高くなるほど著しい.との $60 \%$ 前後の 極小点は異種粒子の存在により同質粒子間の焼結が妨害 されるととに基因するもので曲線の両端部が上方に偏し ているのはこの影響が少ないためと考えられる．またて の極小点が $\mathrm{ZrO}_{2}$ 側にずれているのは $\mathrm{MoSi}_{2}$ の融点 $\left(2030^{\circ} \mathrm{C}\right.$ ) と $\mathrm{ZrO}_{2}$ 固溶体の融点 (約 $2500^{\circ} \mathrm{C}$ ) による焼 結温度の相異によるものと考えられる. また焼結温度に 対して $\mathrm{ZrO}_{2}$ 約 $60 \%$ 前後の組成で密度曲線の逆転が認 められる.すなわち初め焼結温度の上昇につれて高密度 值を示していたのが $\mathrm{ZrO}_{2}$ 含有約 $40 \%$ から $65 \%$ にわ たって反対に低密度值となってくる.

図-2 は温度別 焼結試料の密度比 を組成を因子とし て焼結温度の関数 としてプロットし たものである。 $\mathrm{ZrO}_{2}$ 含有 $40 \%$ 以 下および $100 \%$ 組 成の試料は焼結温 度上昇とともに密 度が増加している が 60\% 組成では 逆に減少してい る. $\mathrm{ZrO}_{2} 0 \%$ 組 成では $1550^{\circ} \mathrm{C}$ 付

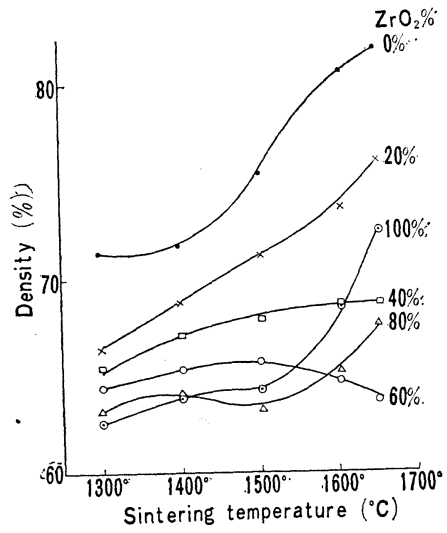

Fig. 2. Relations between density and sintering temperature for each composition.

近から飽和点に近づく傾向を示しているが，20\% 組成 ではその傾向が見られずまだ焼結不完全を示すものと考 えられる. $\mathrm{ZrO}_{2} 40 \%, 60 \%$ 組成の試料ではそれよりさ らに焼結が不完全で $60 \%$ 組成試料のカーブの下がりは 初期加熱過程の 熱膨脹による 密度低下の 段階と 推察さ 
れ,とのととは 前述の異種粒子 による焼結妨害 の影響と思われ る・てれが 図-1 における $\mathrm{ZrO}_{2}$ $60 \%$ 組成付近 で密度曲線の逆 転を生ずる理由 であろう。

図-3 は $1600^{\circ}$ C の焼結温度で 時間別焼結試料 の密度比を燒結 時間を因子とし て成分組成の関

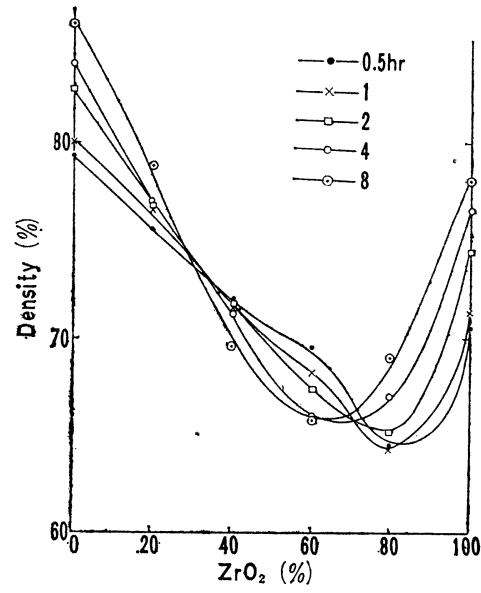

Fig. 3. Relations between density and composition for various sintering times at $1600^{\circ} \mathrm{C}$.
数としてプロットしたものである. 全体の傾向は 図-1 の温度別試料の密度比対組成の曲線と同一で $\mathrm{ZrO}_{2} 60$ $80 \%$ 組成に 極小点が見られ，また 30〜70\% の中間組 成で曲線が逆転交叉している。乙のととは温度別試料に 関する考察と同様江考元られる．また極小点が焼結時間 が增加するとともに $\mathrm{MoSi}_{2}$ 側にずれる傾向があるの は, $\mathrm{ZrO}_{2} 80 \%$ 以上の組成では時間の経過にしたがい $\mathrm{ZrO}_{2}$ 粒子の焼結が顕著になるからと考元られる.

燒結時間に対する 関係をみると $\mathrm{ZrO}_{2} 20 \%$ 以下の組 成及び $80 \%$ 以上の組成は焼結時間の増加とともに密度 が上昇してくる. しかし $\mathrm{ZrO}_{2} 40 \%$ 及び $60 \%$ の組成 のものでは逆に低下してくる。てれもまた図-2 につい ての考察と同様と考えられる。

\section{2 抗 折 力}

図-4 は温度別燒結試料の 抗折強度を焼結温度を因子

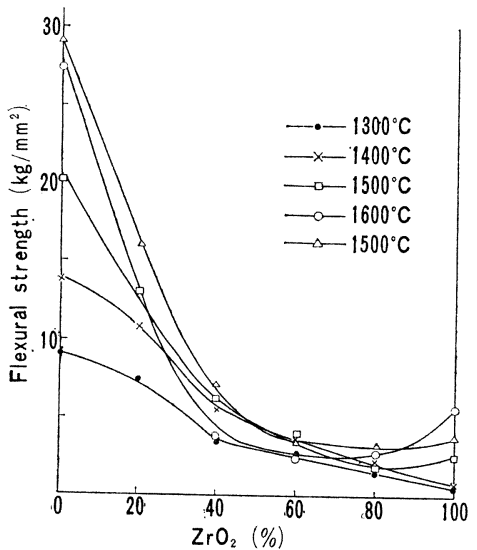

Fig. 4. Relation betweens flexural strength and composition for various sintering temperatures. に対してプロッ トしたもので， 図-1 の温度別 焼結試料の密度 対組成にほほ対 応した傾向を示 しているが， $\mathrm{ZrO}_{2}$ 含有量の 增加とともに急 激に抗折力が減 少してくる．焼 結温度に対する 関係もまた図一 1 の考察と同様 の傾向を示して

\section{3 常温電気抵抗}

図-5 は温度別焼結試料の 常温電気抵抗値を焼結温度 を因子として成分組成に対してプロットしたもので， $\mathrm{ZrO}_{2}$ 含有量が増加す ると比抵抗が大きくな っているが，40\% 以 下ではいずれもきわめ て小さい值を示しほと んど金属的導電性であ る.これは絶縁体であ る $\mathrm{ZrO}_{2}$ の含有量が少 ないために，その電気 伝導は $\mathrm{ZrO}_{2}$ 粒子を介 在する $\mathrm{MoSi}_{2}$ 粒子の 結合ブリッジを通じて 行なわれるためと考光 られる. $\mathrm{ZrO}_{2} 60 \%$ 以 上の組成になると急激 に抵抗が 增加し $80 \%$ 以上では $10^{10} \Omega-\mathrm{cm} の$ オーダーでほとんぞ絶

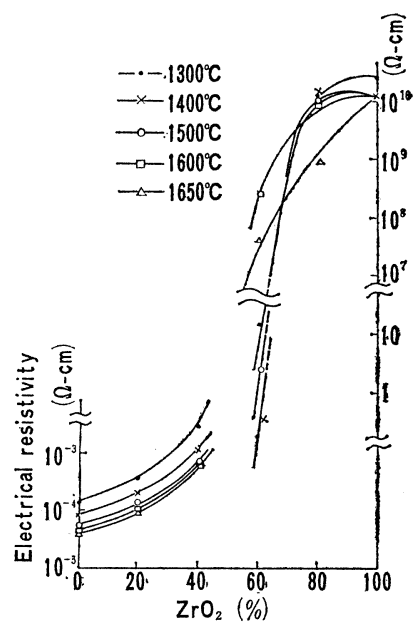

Fig. 5. Relations between electrical resistivity and composition for various sintering temperatures.
縁物である。これは逆汇絶緑物の $\mathrm{ZrO}_{2}$ によって電気伝 導度が支配されるものと考えられる。

焼結温度に対する関係をみると $\mathrm{ZrO}_{2}$ 含有 $40 \%$ 以下 の低抵抗試料の比抵抗は烧結温度上昇とともに減少し， 図-2 の密度が焼結温度とともに增加することに対応し ており焼結が進んだためと考えられる. $\mathrm{ZrO}_{2}$ 含有 $60 \%$ 組成でその抵抗值に大きなばらつきが見られるのは組成 60\% 付近が抵抗の 高い方へ急激に上昇する 境目の組成 であるために僅かの混合度，焼結度の相異が比抵抗值に 大きく影響してくるのであろう。

III. 4 高温における電気抵抗値の变化 いる。
水素中 $1600^{\circ} \mathrm{C}$ で 1 時間焼結した各組成の試料につい

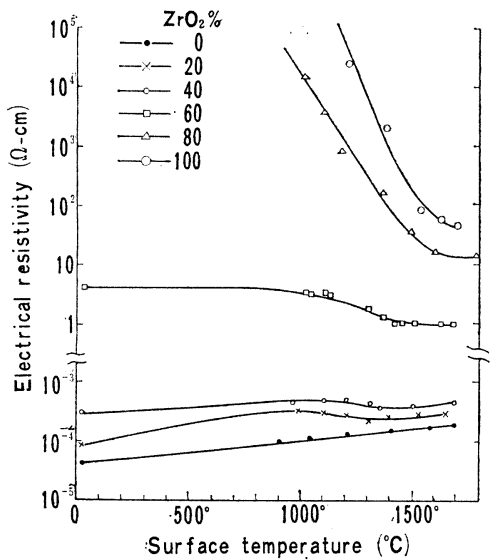

Fig. 6. Change of electrical resistivity with temperature. (Sintered at $1600^{\circ} \mathrm{C}$ for one hour) 
て $900^{\circ} \sim 1700^{\circ} \mathrm{C}$ までの電気抵抗值の変化を測定した結 果を 図-6 に示す. $\mathrm{MoSi}_{2}$ 100\% 組成の試料は温度とと もに直線的に比抵抗が増加し金属的導電性を示してい る. 一方 $\mathrm{ZrO}_{2} 100 \%$ 組成の試料は温度上昇とともに急 激に抵抗が減少し $1700^{\circ} \mathrm{C}$ の表面温度では約 $40 \Omega-\mathrm{cm}$ に達する. E. Ryshkewitch ${ }^{3)}$ による $\mathrm{Y}_{2} \mathrm{O}_{3} 15 \mathrm{wt} \%$ を 固溶する $\mathrm{ZrO}_{2}$ の $1650^{\circ} \mathrm{C}$ の比抵抗值は $0.75 \Omega-\mathrm{cm}$ で, てれに比して测定值はかなり高い。このことは本実験の 焼結温度が低すぎるため到達密度が比較的低いこと, ま たカーボン管による間接加熱であるため試料温度は測温 したカーボン発熱体の表面温度より低いということも原 因の一つではなからうか.

組成中 $\mathrm{ZrO}_{2}$ が増すとともに比抵抗值は増加し $0 \%$ と $100 \%$ 組成との中間のカーブを示す. $\mathrm{ZrO}_{2} 80 \%$ 組成で は抵抗がやや低いのみでほぼ 100\% 組成と同様温度上 昇とともに抵抗が減少する。

\section{5 熱衝撃試験}

水素中 $1600^{\circ} \mathrm{C}$ で 4 時間焼結した試料について行なっ た熱衝撃試験の結果を 表-1 に示す. 中間組成のもの, 特に 60\%のものが熱衝撃抵抗が低く両端の単一成分組 成すなわち異種粒子の少ないものほど高い傾向を示す.

Table 1. Result of thermal shock test.

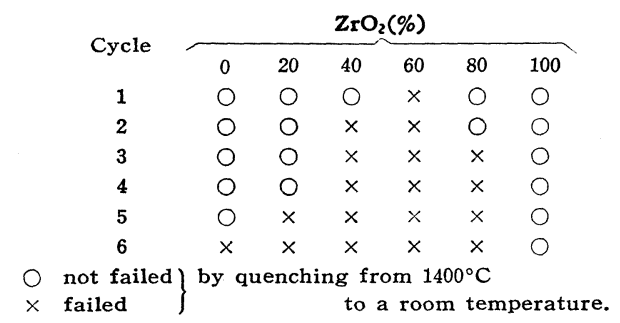

中間組成のものが熱衝撃に弱いのは異種粒子の存在によ る 密度低下と 熱膨脹の差によるものではなかろうか.
ちなみに $\mathrm{MoSi}_{2}$ の熱膨脹係数は $8.1 \times 10^{-6} /{ }^{\circ} \mathrm{C}^{4)}(20$ $1500^{\circ} \mathrm{C}$ ) であり（本実験による測定值は $8 \times 10^{-6} /{ }^{\circ} \mathrm{C}$ ), $\mathrm{ZrO}_{2}$ は $8.8 \sim 11.8 \times 10^{-6} /{ }^{\circ} \mathrm{C}\left(0^{\circ} \sim 1000^{\circ} \mathrm{C}\right)^{5)}$ である.

\section{IV. 結 論}

(1) $\mathrm{ZrO}_{2}$ に $\mathrm{Y}_{2} \mathrm{O}_{3} \quad 10 \mathrm{~mol} \%$ 固溶 せしめて安定化 $\mathrm{ZrO}_{2}$ を得るには $1600^{\circ} \mathrm{C} 8$ 時間加熱処理で十分である.

(2) $\mathrm{ZrO}_{2}$ が增すに従って密度が減少し約 $60 \%$ 付 近で極小となり，再び上昇してくる．ての $60 \%$ 付近の ものは焼結温度に対して逆に密度が減少し, 両端組成の ものに比して焼結しにくい，また焼結時間に対しても同 様の傾向である.

（3）抗折力はほぼ密度に対応する変化を示す.

（4）常温電気抵抗は $\mathrm{ZrO}_{2}$ 增加とともに増大し 60 $\%$ 付近加急激に増加し絶縁体に近づく. 電気抵抗値 としてはこの $60 \%$ 付近のものが最適であるが焼結条件 のコントロールが困難である.

(5) 高温における電気抵抗值の変化は $\mathrm{MoSi}_{2}$ 側に よった組成は温度上昇とともに抵抗が增加するが, $\mathrm{ZrO}_{2}$ 側は減少する.中間組成のものはこの中間 カーブを描 $<$.

（6）熱衝撃抵抗は中間組成のものが最も弱い.

\section{文}

1) P. Duwez, F. Odell \& F.H. Brown. J. Electrochem. Soc., 98, 360 (1951)

2) F. Hund. Z. Electrochem., 55, 365 (1951)

3) E. Ryshkewitch. Oxide Ceramics, Akademic Press, London (1960)

4) Molybdenum Chemicals, Bulletin Cdb-6A, May (1963)

5) C.E. Curtis. J. Am. Ceram. Soc., 30, 180-196 (1947)

\section{シリカと燐酸アルミニウムとの固溶について}

クリストバライトとクリストバライト型燐酸アルミニウムとの固溶

\section{小林 種 雄 (名古屋工業大学案業工学科)}

\section{Solid Solution of Cristobalite and Cristobalite-type $\mathrm{AlPO}_{4}$.}

By

Taneo KOBAYASHI

(Dept. of Ceramics, Nagoya Institute of Technology, Nagoya City)

As part of the investigation of the system $\mathrm{SiO}_{2}-\mathrm{Al}_{2} \mathrm{O}_{3}-\mathrm{P}_{2} \mathrm{O}_{5}$, solid solution of $\mathrm{SiO}_{2}$ and $\mathrm{AlPO}_{4}$, both of cristobalite structure, was studied.

At first it was confirmed that $\mathrm{AlPO}_{4}$ can be formed from $\mathrm{Al}(\mathrm{OH})_{3}$ and $\mathrm{H}_{3} \mathrm{PO}_{4}$ by 